\title{
Human Anti-Mouse Antibody
}

National Cancer Institute

\section{Source}

National Cancer Institute. Human Anti-Mouse Antibody. NCI Thesaurus. Code C18062.

Human antibodies which recognize mouse antibodies. These often develop in response

to treatment with antibodies and limit the effectiveness of the treatment. 